\title{
Sefarad But Not Spain: The Settlement of Jews in Gibraltar, 1704-1783
}

\author{
LORRAINE MADWAY *
}

Jews arrived in Gibraltar shortly after a combined force of English and Dutch soldiers occupied the Rock in 1704, during the War of Spanish Succession. Most of them were descendants of "gerushim" who left Spain in 1492 and went to northern Morocco. The struggle of Jews to settle and establish a community in Gibraltar parallels and, indeed, is a result of the struggle of the British to control the fortress whose strategic position they had long appreciated ". Initially, Jewish merchants and interpreters made themselves useful by providing commercial and diplomatic services to the garrison that no one else could provide. Just as the British occupation withstood the test of repeated Spanish assaults during the course of the eighteenth century, so too, did Jews manage to rebuff the periodic attempts of British governments to remove them. Through service and persistence, Jews finally won the right to settle in the town and establish a community. The presence of a flourishing Sephardic community within plain view of Spain's shores is surely one of the ironies of Spanish-Jewish history which makes its study a subject of continuing fascination.

In the following paper I shall analyze the eighteenth-century settlement of Jews in Gibraltar from three perspectives: the larger geo-political context, the internal dynamics of the Jewish community, and the interaction of Jews with other segments of the population in the fortress. Due to the insufficiency of primary sources for this period, particularly Jewish records, and my newness to the subject matter, much of my work is based on the research of other historians, particularly that of Mesod Benady ${ }^{2}$. Naturally,

* Yale University.

See Hills, Gearge, Rock of Contention: A History of Gibraltar. London 1974.

2 See Benady, Mesod, "The Settlement of Jews in Gibraltar, 1704-1783", Jewish Historical Society of England [hereafter TJHSE ] Transactions, 26, 1979, págs. 87-110; and ibidem, "The 
I take full responsibility for the interpretations that I make and the conclusions that I draw.

\section{TANGIER, $1662-1684$}

It is hardly surprising that the first Jewish settlers in Gibraltar were Jewish merchants, mostly from northern Morocco, who provided the English and Dutch forces with essential goods and services. Morocco was the most convenient source for fresh provisions, horses and building materials, and the forces relied on Jewish merchants' skills and contacts to purchase and transport the supplies and serve as intermediaries in their dealings with local Moroccan rulers like the sultan Mulay Ismael and the alcaide Aly Benandola. What is generally ignored is the question of how these merchants were able to develop a commercial and diplomatic relationship so quickly with the allied forces, particularly the English who provided most of the manpower and money for the fortress. Within just two years, English sources disclose that there were already a substantial number of Jewish merchants living in the town ${ }^{3}$. The fact of the matter is that the arrival of Jewish merchants in Gibraltar was a continuation of English-Jewish commercial and diplomatic contacts dating from the English occupation of Tangier from 1662 to 1684 .

Tangier was a valuable colonial possession in the early modern period. It provided its owner with a strategic base for expansion to northern Africa, the far East and the New World, and its acquisition was worthy of diplomatic intrigue if not outright warfare. The Portuguese had held onto Tangier since the end of the fifteenth century. They agreed to give it up (along with Bombay) when they needed England's help in their protracted war of independence from Spain. During their brief occupation, the English, like the Portuguese, relied on Moroccan Jews for commercial and diplomatic services. For the four years between 1667 and 1671 when England was not helping the Portuguese or fighting the Dutch, Tangier prospered commercially and every indication that it could become the most important trading center in the Mediterranean ${ }^{4}$. Since Jewish merchants controlled most of the local trade, they formed a network of commercial contacts with the English which would later prove mutually beneficial when England occupied Gibraltar some thirty years later.

Jewish Community of Gibraltarn, in The Western Sephardim, vol. II, The Sephardi Heritage, ed. Richard Barnett. London 1989.

${ }^{3}$ Report of BENNET, Colonel, British Library (hereafter BL) Add. ms. 10,034.

4 Hills, Rock of Contention, pág. 149. 
Relations between the English and the Jews in Tangier markedly deteriorated after 1675 when internal discord within the Moroccan Jewish community curiously converged with the religiously-charged atmosphere of domestic English politics and changes in diplomatic personnel. A serious dispute broke out between the "toshavim", Jews of native Moroccan background, and the "megorashim", descendants of Castilian Jews who went to Morocco directly from the Iberian peninsula or by way of Holland or Livorno (Leghorn) ${ }^{5}$. That same year Charles II appointed William O'Brian, Lord Inchiquin, a Catholic, as Governor of Tangier. He expelled the Jews from the city in 1677. When Inchiquin's naval chaplain, Titus Oates, was dismissed from the navy and later conspired in the fantastic "plot» for which he is better remembered, Tangier came to be associated with Popish plots. Parliament refused to spend any more money on its development or even to maintain the garrison. In 1680 Inchiquin was dismissed as governor and the Jews were permitted to return to the town. They had little reason to stay after the English finally abandoned Tangier in 1684, and the short but fruitful commercial relationship between England and Moroccan Jews came to a halt. The English occupation of Gibraltar two decades later made its revival urgent for the soldiers, attractive to the merchants, and complicated for the politicians.

\section{JEWISH SETTLEMENT BEFORE THE TREATY OF UTRECHT, 1705-1713}

Within a few years after England took control of the fortress, the three hundred Jews who lived there comprised about one-third of the civilian population of Gibraltar ${ }^{6}$. During this time Gibraltar existed in a state of diplomatic limbo: it was under de facto British ${ }^{7}$ control but still de jure a part of the Spanish empire. But the continuing need for the commercial and financial services which Jewish merchants and artisans provided overcame the legal ambiguity of their position. Further, they enjoyed the support of Moses Benatar, treasurer and financial advisor to the Moroccan ruler Mulay Ismael. Although Benatar never settled in Gibraltar, he had substantial business interests there and made most of the emperor's pur-

\footnotetext{
s FIRTH, C. H., "Some Historical Notes, 1648-1680", TJHSE Transactions, 4, 1899-1901, págs. 198-200; Corcos, David, “Tangier», Encyclopedie Judaica, vol. 15, pág. 791; ibidem, «Morocco", in ibidem, vol. 12, págs. 331 and 335 .

6 According to Benady, the Jews constituted half of the civilian poopulation in 1711 and, with rapid population shifts, one-third of the population in 1713. See "The Jewish Community of Gibraltar", págs. 146-147.

7 England became part of Great Britain in 1707. To be precise, then, England occupied Gibraltar in 1704 whereas Great Britain acquired it in 1713.
} 
chases through his agents in Gibraltar. When one of the governors, Roger Elliot, became excessive in his demands for bribes and payoffs from the Jewish residents, Benatar had the emperor retaliate by imposing a partial blockade «until the Queen [Anne] made it a free port as well for Moors as for Jews" ${ }^{8}$.

A list of rents compiled by the army inspectors in 1712 reveals useful information about the origins of the Jewish population. In addition to the majority who came from northern Morocco, especially Tetuan, there were the two sons of Rabbi David Nieto of London (Isaac and Phineas), the Cardozo brothers from Portugal, and a few references to Jews from Livorno ${ }^{9}$. A year earlier, the chief military engineer of the garrison, Colonel Bennett, provided additional information in one of his reports: "The Jews come daily in great numbers from Barbary. Leghorn and Portugal to inquire into every particular circumstance of the place, they have their correspondents abroad ..." ${ }^{10}$.

The records also disclose the presence among the settlers of conversos who wanted to convert (or possibly revert) to Judaism. In 1713 a Franciscan friar, Father Balbuena, complained that both he and a Marrano physician were expelled from Gibraltar for purely financial reasons. He described the unnamed man as "a Physician from Spain a Jew very able and utile for the good of the garrison" who was expelled "under the pretence of his havin circumcized and married in the Town" ". The truth was that the doctor, like the priest, had refused to yield to the governor's extortionate financial demands and she was turned out and went to Amsterdam". The priest also mentioned that in his dealings with the governor he had employed "a Jew called Ximenes" who acted as intermediary. It is not clear whether Ximenes was another Marrano settler or one of the few Spaniards who remained in 1704. Finally, Benady refers to the research of Derek Davis in the archives of the Inquisition in Malta which shows that some of the Marranos in Gibraltar were refugees from a cryptoJewish community in Seville ${ }^{12}$.

In 1713 the British tried to alter the ethnic balance of the population by encouraging people from England to settle in Gibraltar. The government preferred Protestants, but English Jews were acceptable, or at least pre-

\footnotetext{
Report of Colonel Bennett, BL Add. ms. 10,034.

Public Record Office (hereafter PRO), Colonial Office (hereafter CO), 91, pág. 1.

Report of Colonel Bennett, BL Add. ms. 10,034.

PRO, CO. 91, pág. 1

See DAVIS, Derek, "The Inquisition of Malta and the Jews", Lecture to TJHSE, February 1985, cited in BENADY, "The Jewish Community of Gibraltar", pág. 147.
} 
ferable to non-English Jews. This preference may be inferred from the petition of Jacob (Manuel) Diaz Arias who stated that he moved to Gibraltar "by encouragement of [the governor] the Earl of Portmore» ${ }^{13}$. But most of the "poor English" who went to Gibraltar found that they could not compete with the Genoese, Jewish and Spanish hawkers, artisans and laborers who were already there. Nor were they happy with the confining and regimented quality of daily life. Benady points out that military discipline regulated many aspects of the civilians' lives, including the colors of their houses and the times they were permitted out of doors ${ }^{14}$. While such restrictions were onerous to people from England, they were far less restrictive and capricious than many of the conditions to which Moroccan Jews were accustomed. Experts in the art of survival, Jews welcomed the economic opportunities of Gibraltar and learned to maneuver themselves in the political arena where the British now made the rules.

\section{THE TREATY OF UTRECH AND ITS AFTERMATH, 1713-1727}

The most difficult political challenge facing Jewish settlers in Gibraltar was the determination of the British government in London to comply with the requirements of the Treaty of Utrecht. This agreement, completed in April 1713 and signed in August, established peace between Great Britain and the United Provinces on one side and Spain on the other. Article 10 of the treaty required, among other things, that Britain agree to "the request of the Catholic King ... that no leave shall be given under any pretence whatsoever, either to Jews or Moors, to reside or have their dwellings in the said town of Gibraltarm ${ }^{15}$. That the British government succeeded in enforcing this prohibition only from 1718 to 1720 was due, as Sir Joshua Hassan points out, to the corruption of the local authorities in Gibraltar and the need to obtain provisions from Morocco in light of Spain's refusal to supply them ${ }^{16}$. A report by a visiting Catholic bishop disclosed that prior to 1718 , there were about 300 Jews living in Gibraltar and they even had their own synagogue ${ }^{17}$.

Britain's reliance on Morocco proved to be highly advantageous to the Jewish settlers. They gained not only substantial profits from their parti-

13 PRO, CO. 91, pág. 1. Petition of Manuel Diaz Arias.

14 BENADY, “The Jewish Community of Gibraltar", pág. 147.

15 Sir HASSAN, Joshua, The Treaty of Utrecht 1713 and the Jews of Gibraltar THJSE. London 1970, pág. 1.

16 HASSAN, pág. 3.

17 See Bethencout MASSieu, Antonio de, El Catolicismo en Gibraltar durante el siglo XVIII. Valladolid 1967, pág. 19. 
cipation as traders and financiers, but also the legal protection and recognition which the British granted to Moroccan subjects in a peace treaty concluded in 1721. Article 7 gave English merchants the right to settle in and trade with Morocco, and stipulated that ithe subjects of the Emperor of Fez and Morocco, whether Moors or Jews, residing in the dominions of the King of Great Britain, shall entirely enjoy the same privileges that are granted to the English residing in Barbary" ${ }^{18}$. For all practical purposes, this article neutralized Article 10 of the Treaty of Utrecht without even mentioning Gibraltar. Article 13 even gave Jews residing in Gibraltar what amounted to de facto naturalization: «every person ... whether Spaniard, English or otherwise ... living or residing there [i.e., Gibraltar and Minorca], shall be esteemed as [His Majesty's] natural born subjects»" ${ }^{19}$.

The services and supplies which Jews furnished to the garrison during the siege of 1727 helped them achieve what no treaty could provide or negate: acknowledgement of the importance of their presence and even a modicum of respect for the way that some of them handled themselves during the hostilities. In his account of events, Daniel Defoe recorded that "the Jews were not a little serviceable, they wrought in the most indefatigable manner, and spared no pains when they could be of any advantage, either in the siege or after it» ${ }^{20}$. Although the authorities continued to turn out poor Jews and topay intermittent lip service to the Treaty of Utrecht, they took no further steps to expel most of the Jewish residents. The Spanish blockade of Gibraltar during the next twenty-five years mainly serviced to reinforce British reliance on Jewish merchants. After 1727 the economic prospects of the fortress and relative security of the Jews' political position in Gibraltar attracted a substantial number of Jewish settlers ${ }^{21}$, and they and their descendants could concentrate on rebuilding a Sephardic community on the edge of their ancient homeland.

\section{ESTABLISHMENT OF THE JEWISH COMMUNITY, 1727-1783}

The predominant characteristic of the Jewish community was its socioeconomic diversity. In addition to a few powerful merchants, there were

is PRO, CO. 91, pág. 7.

19 Ibidem.

20 DeFOE, Daniel, An Impartial Account of the Late Famous Siege of Gibraltar. London 1728, pág. 4.

21 According to BENADY, "The Jewish Community of Gibraltar", págs. 152-153, the greatest increase in the number of the Jews occurred in the twelve years inmediately after the siege of 1727. In 1725 the Jews numbered 137, forming 12 per cent of a total civilian population of 1,113 . In the next census taken in 1753 , they numbered 572 or 32 per cent of the increased population of 1,793 . 
shopkeepers and artisans, including masons, tailors, shoemakers, bakers and butchers, a number of boatmen, an even greater number of hawkers and peddlers, and the elite of the labor force, the porters. Those who were licensed formed their own company of porters.

Social relations between different classes and ethnic groups appear to have been much more tranquil than they had been in Morocco during the previous two centuries. Extant records indicate that there were no conflicts so serious as to come to the attention of the civil authorities or outside observers. The only problem mentioned in the civil records stemmed from the rowdiness of the hawkers and porters. When they were not working, they tended to congregate in the center of town. Their noisy, argumentative and aggressive behavior was a threat to public order and a frequent source of embarrassment to the more affluent members of the community. Humphrey Bland, the most activist governor of Gibraltar during the eighteenth century, authorized "some of the Principal Jews to consider of some method for preventing such inconvenience for the future ${ }^{22}$.

In 1750 the community leaders formulated a number of regulations, which the authorities promulgated, including: «That on their Sabbath day [the Jews] behave themselves so worthy and conformable to the Rules and Orders of their Religion and Rabbi ${ }^{23}$ ". That the leaders found it necessary to address the issue of Sabbath observance in the community suggests that conformity to religious norms was far from universal. The significance of Bland's regulations is the legal approval they gave to the established practice of communal self-governance. Further, it is clear that the civil authorities of Gibraltar were not requiring Jews to relinquish their cultural identity or religious practice as the price of their social integration. To the contrary, the authorities encouraged communal autonomy, even to the extent of authorizing the community to collect certain special taxes for the government ${ }^{24}$.

Relations between Jews and other groups also appear to have been generally good. As Benady observes, «There were no inter-communal incidents, nor the acrimonious exchanges between the Roman Catholic clery and Jews that were a common picture of life in Minorca during the same period" ${ }^{25}$. Ignacio López de Ayala, a well-known Spanish writer of the period, wrote a history of Gibraltar in $1778^{26}$. Although he had little regard

22 Governor Humphrey Bland, Orders Book, 23 July 1750.

23 Ibidem.

24 BENADY, "The Settlement of Jews in Gibraltar", pág. 100.

25 Ibidem, pág. 89.

26 López de Ayala, Ignacio, Historia de Gibraltar. Madrid 1782. 
for the British, he marvelled at how well the British authorities governed Gibraltar:

One would expect the same quarrels and acts of violence in Gibraltar, because of the diversity of religious interests and customs, as one gets in the other cities of the Province [of Andalucia]. The strictness of the military government has, however, prevented them; because everybody knows the punishment they will receive if they commit a crime, as the officials cannot be bribed nor the judges coerced, everyone's security is based on not encroaching on the rights of others; and as a result of the well-established and observed system of law and order, many years pass without the murders and violent deaths that occur in other towns, which are smaller and have inhabitants who are all of the same religion and way of life ${ }^{27}$.

Ayala had even less regard for Jews than he had for the British. Unlike his treatment of the British, he had virtually nothing good to say about Jews. Surprisingly, his visit to Gibraltar provided him with only a few additional scurrilous details of Jews' behavior. For example, he mentions the "notorious beauty" of the young second wife of Isaac Aboab, the richest Jewish merchant of his era and the leader of the Jewish community ${ }^{28}$. Ayala mistakenly assumed that her reason for wearing a wig was a lack of hair rather than religious modesty. What scandalized Ayala was not her appearance or even her husband's bigamy ${ }^{29}$, but that polite Christian society in Gibraltar socialized with her and the other members of the Jewish mercantile elite.

The far-flung business interests and familial connections of Jewish merchants in Gibraltar provided them with contacts not only in Morocco, England, Italy and the Netherlands, but the West Indies and even Spain. Henry Charles Lea uncovered several references from the inquisitorial records of Valencia which showed that Jews from Gibraltar were trading in Spain. In 1759 a Jew came with merchandise from Gibraltar. A familiar from the Holy Office never left him until he sold his goods and departed, and his goods and papers were carefully examined to determine that they contain nothing prejudicial. Several others went in 1761 and 1762 and were treated in the same way ${ }^{30}$. In 1795 a royal order was issued thorugh

27 lbid., pág. 373 .

28 Ibid., pág. 383.

29 Isaac Aboab was already married to Hannah when he married, at age 50 , a 13 year-old girl, Simha, from Tetuan, who must be the woman referred to by Ayala. According to BENADY, "The Settlement of Jews in Gibraltar", pág. 102, Aboab said in his will that because his wife was barren, Jewish law permitted him to take a second wife.

${ }_{30}$ Archivo Histórico Nacional, Inquisición de Valencia, leg. 504, n. 2, cited in LEA, Henry 
the Suprema which permitted a Jewish subject of Morocco to come to Valencia and remain for eight or ten days ${ }^{31}$. This order amounted to a tacit acceptance of the presence of Jews in Gibraltar without requiring Spain to acknowledge British sovereignty over the fortress or its jurisdiction over the Jews who lived there.

According to the census figures available, the civilian population of Gibraltar doubled between 1753 and 1777, increasing from 1,793 to 3,201, but the Jewish population increased by only $50 \%$ from 572 to 863 . At this point the Jews constituted an older and more established segment of the population than the Catholics, and more than $70 \%$ of them had been born in Gibraltar. The wealth of the Jews had increased as well. In 1756 they comprised one-third of the population and owned $20 \%$ of the properties, whereas in 1777 they comprised only $27 \%$ of the population but owned $25 \%$ of the properties ${ }^{32}$.

Within just two years, the Jews, like the rest of the civilian population of Gibraltar, found themselves in danger of losing not just their property but their very lives. In 1779 Spain began preparations for its most serious attempt to recover Gibraltar. During the Great Siege the inhabitants waged a relentless struggle against starvation, disease and frequent bombardment. A substantial number of the civilians left the garrison for England, Minorca or Morocco ${ }^{33}$. When the siege finally ended in 1783, many of the refugees returned to Gibraltar and the survivors began the task of rebuildin their town and their lives.

\section{CONCLUSION}

In their adaptation to life in eighteenth-century Gibraltar, Jews followed the traditional Sephardi model of service to the rulers and commercial enterprise. As medieval Spain, the model functioned within the setting of "convivencia". The success of the model in Gibraltar would surely have

Charles, A History of the Inquisition of Spain, Ill. New York 1907, pág. 313 (leg. cited according to an older system as leg. 4).

${ }^{31}$ Ibidem, leg. 504, n. 3, fol. 222.

32 BENADY, "The Jewish Community of Gibraltar", págs. 155-156.

${ }_{33}$ ANCELL, S., A Journal of the Blockade and Siege of Gibraltar. Dublin 1802, pág. 31; DrinkWATER, John, A History of the Siege of Gibraltar, 1779-1783. London 1905, págs. 133-138, 167, 335; Mrs. GREEN, "A Lady's Experience in the Great Siege of Gibraltar", Royal Engineers Journal, July 1912, pág. 33; SpILSBury, Capitain John, An Authentic and Accurate Journal of the Siege of Gibraltar. London 1785, pág. 27; RuBENs, Alfred, "Portrait of Anglo-Jewry, 1656-1836", TJHSE Transactions, 19, 1960, pág. 18. 
impressed Solomon Ibn Verga and Samuel Usque, two of its greatest proponents.

Can the "convivencia", past and present, of Gibraltar be duplicated elsewhere or does it represent the unique convergence of historical circumstances? The answer to this question takes us beyond the realm of history and into those of contemporary politics and social relations. What the history of Jewish settlement in Gibraltar during the eighteenth century does reveal is a time and a place where Jews, Catholics and Protestants understood that "convivencia" is not the result of historical inevitability or accident but the culmination of human effort and struggle.

\section{ACKNOWLEDGEMENTS}

I would like to acknowledge the encouragement I received during my research trips to Gibraltar form Sir Joshua Hassan and Mesod Belilo. Both of them generously shared their time and their knowledge. I would also like to thank Thomas Finlayson, James Levy, John Searle and Father Charles Caruana, who were also very helpful. 